ACTA UNIVERSITATIS LODZIENSIS

FOLIA LITTERARIA POLONICA 5(35) 2016

http://dx.doi.org/10.18778/1505-9057.35.08

Rafał Siekiera*

\title{
Reportorial or Essayistic Paradigm? - a Few Remarks about the Sports Report
}

The report is traditionally classified as an informational genre. However, even a cursory look at definitions proposed by individual researchers reveals the tendency to omit features characteristic of a sports report.

The aim of this work is to examine modern sports reports ${ }^{1}$ from the perspective of literary genetics and attempt to determine their features and place in the continuum of genres.

The classical concepts of literary genetics treat sports reports quite unambiguously. According to Jacek Maziarski, it is "a matter-of-fact, concise and topical press, radio or television coverage of the course of some event [...]. The report is also considered to be related to news [...]"2. The similarity to press information is decided by the use of similar means of expression, its conciseness, and the matter-of-fact attitude towards presenting the course of events ${ }^{3}$. Kazimierz Wolny-Zmorzyński, who takes a similar position, additionally emphasizes the necessity to retain the chronological order of presenting the facts and the impartiality of the author ${ }^{4}$. Marek Chyliński and Stefan Russ-Mohl even call the sports report "longer news" 5 and perceive the detailed approach to presenting the facts (also in chronological order) as its essence.

* Dr, e-mail: rafal.siekiera@onet.eu; The University of Lodz, Faculty of Philology, Department of Journalism and Communication; ul. Pomorska 171/173, 90-236 Łódź.

${ }^{1}$ Press publications considered in the study are defined as reports, although occasionally one may also come across the term 'coverage' (pol. 'relacja'). On the subject of terminological differentiation between sports report and coverage see: B. Grochala, „Komentarz (sportowy), relacja (sportowa), sprawozdanie (sportowe) - przegląd stanowisk”, Acta Universitatis Lodziensis. Folia Litteraria Polonica 2012, No. 3, pp. 95-105.

2 J. Maziarski, „Sprawozdanie”, in: „Encyklopedia wiedzy o prasie”, ed. J. Maślanka, Zakład Narodowy im. Ossolińskich, Wroclaw 1976, p. 224.

${ }^{3}$ Ibid., pp. 224-225.

${ }^{4}$ Cf. K. Wolny-Zmorzyński, „Sprawozdanie”, in: „Słownik terminologii medialnej”, ed. W. Pisarek, Universitas, Cracow 2006, p. 201 and K. Wolny-Zmorzyński, A. Kaliszewski, „Gatunki informacyjne”, in: K. Wolny-Zmorzyński, A. Kaliszewski, W. Furman, „Gatunki dziennikarskie. Teoria, praktyka, język", Wydawnictwa Akademickie i Profesjonalne, Warsaw 2009, p. 44.

${ }^{5}$ M. Chyliński, S. Russ-Mohl, „Dziennikarstwo”, Grupa Wydawnicza Polskapresse, Warsaw 2008, p. 63. 
Zbigniew Bauer indicates the possibility of departing from the temporal order in favour of that of cause and effect; however, he also classifies the sports report as an informational genre and considers acquainting the reader with the course of events ${ }^{6}$ as its most important task.

According to Janina Fras, the most vital components of a report include descriptions, summaries and comparisons to past events?

The aforementioned features obviously set the genre in question among the forms of expression which belong to the informational kind. In accordance with determinants found in the literature ${ }^{8}$, these types of texts are created with a view to inform about topical and socially important facts and are characterized by their pursuit of objectivism, accuracy, compactness of the message, and assertiveness, understood as presenting only the facts without speculations, judgements and conjectures; furthermore, they avoid interpreting the events. In the linguistic sphere, the informative genres are set apart by depersonalization of the message, conventionality, communicativeness, precision and the lack of stylistic superstructure in the form of devices which distract from the content (the fact is more important than the way in which it is conveyed), make the text more appealing or affect the reception of information.

The traditional perspective presented above is incompatible with the sports report. In the case of sports journalists, the majority of the aforementioned features are either marginalized or even not applicable. This is relevant to the factual, functional and linguistic sphere.

The concepts of literary genetics proposed by Edward Balcerzan ${ }^{9}$, Janina Fras ${ }^{10}$ and, indirectly, Maria Wojtak ${ }^{11}$ are useful to better characterize the genre. An attempt to unambiguously classify the sports report into one of the traditionally dis-

${ }^{6}$ Cf. Z. Bauer, „Gatunki dziennikarskie”, in: „Dziennikarstwo i świat mediów”, ed. Z. Bauer, E. Chudziński, Universitas, Cracow 2010, p. 267.

7 J. Fras, „Dziennikarski warsztat językowy”, $2^{\text {nd }}$ ed., en., rev. ed., Wydawnictwo Uniwersytetu Wrocławskiego, Wroclaw 2005, p. 86.

${ }^{8}$ Cf. i.a. J. Maziarski, „Informacja”, in: „Encyklopedia wiedzy”, op. cit., pp. 107-109; K. WolnyZmorzyński, A. Kaliszewski, op. cit., pp. 37-86; M. Chyliński, S. Russ-Mohl, op. cit., p. 54-68; Z. Bauer, op. cit., p. 263-269; M. Wojtak, „Gatunki prasowe”, Wydawnictwo Uniwersytetu Marii Curie-Skłodowskiej, Lublin 2004; J. Fras, op. cit., p. 82; A. Kozieł, „Gatunki dziennikarskie - rodowód, cechy i funkcje”, in: „O warsztacie dziennikarskim”, ed. J. Adamowski, Oficyna Wydawnicza Aspra JR, Warsaw 2002, p. 111; J. Wegner, „Metoda systematyzowania form dziennikarskich”, in: „Metody i techniki badawcze w prasoznawstwie”, Vol. 1, ed. M. Kafel, Wydawnictwa Uniwersytetu Warszawskiego, Warsaw 1969, pp. 130-144; A. Wtorkiewicz, „Stylistyka prasoznawcza - szkic problematyki i metod”, in: „Metody i techniki badawcze w prasoznawstwie”, Vol. 3, ed. M. Kafel, Wydawnictwa Uniwersytetu Warszawskiego, Warsaw 1971, pp. 114-121.

${ }^{9}$ E. Balcerzan, „W stronę genologii multimedialnej”, Teksty Drugie 1999, No. 6, pp. 7-24.

${ }^{10} \mathrm{~J}$. Fras, „O typologii wypowiedzi medialnych i dziennikarskich”, Wydawnictwo Uniwersytetu Wrocławskiego, Wroclaw 2013.

${ }^{11}$ M. Wojtak, „Gatunki”, op. cit. 
tinguished genres of journalism is doomed to failure. This stems from the fact that individual texts fulfil the principles of the genre to a varying degree. Hence the importance of Balcerzan's multimedial triad; in accordance with this proposition, one should talk of quasi-generic paradigms, differentiated on the basis of their illocutionary dominant. They include the following intentions: feuilletonistic (its objective is the critical, common-sense driven and playful survey of stereotypes ${ }^{12}$ ), essayistic (characterized by, among others, contemplativeness and discursiveness ${ }^{13}$ ) and reportorial (informing about the actual state of things" ${ }^{14}$ ). In line with the description presented by the author, the report should be classified among the genres which fulfil the reportorial intention. However, taking into account the collected resource material, one may acknowledge that the sports report transcends this paradigm.

More helpful is the idea that genres represent typological concepts, which means that they are abstract models. Particular texts resemble these models to a lesser or greater extent, but they are never fully realized ${ }^{15}$. Because of this, it is reasonable to use concepts of types (ideal and empirical) ${ }^{16}$. According to Fras, both abstract conventions (ideal types) and concrete utterances (empirical types) which realize them may constitute the subject of research. Since the continuum of genres of speech is based on the principles of family resemblance ${ }^{17}$, the texts may recreate more than one model. Fras calls such utterances multigeneric or heterogeneous $^{18}$. It appears that the sports report falls into this category.

There is little doubt that it informs about certain facts, which are surely topical. It is usually published the day after the end of the events it concerns. Because of these two features, the sports report is closer to the reportorial paradigm. It also answers the basic questions of journalism, although not necessarily all of the ${ }^{19}$; the order in which it does that is largely dependent on the author's inventiveness.

The sports report does not adhere to the traditional structural pattern of information, that is the so-called inverted pyramid, even though individual elements of these texts overlap with the structure of news.

\footnotetext{
${ }^{12}$ E. Balcerzan, „W stronę genologii”, op. cit., p. 23.

13 Ibid., p. 22.

${ }^{14}$ Ibid., p. 21.

${ }^{15}$ On the subject of genres as typological concepts cf. J. Maziarski, „Metodologiczne problemy nauki o gatunkach dziennikarskich”, in: „Metody i techniki”, Vol. 1, op. cit., p. 120.

${ }^{16}$ Cf. S. Gajda, „Gatunkowe wzorce wypowiedzi”, in: „Współczesny język polski”, ed. J. Bartmiński, Wydawnictwo Uniwersytetu Marii Curie-Skłodowskiej, Lublin 2012, pp. 255-268.

${ }^{17}$ These kinds of claims were inspired by the theories of Ludwig Wittgenstein and Eleanor Rosch.

18 J. Fras, „O typologii”, op. cit., p. 116.

${ }^{19}$ For example, questions such as: who?, when?, how? (in what way?), why? may be omitted. The journalists do not often make it obvious where a match, race or a fight took place (the recipients usually know that anyway); it also happens that there is no information as to the way in which, for instance, a goal was scored. The contents of a report largely depend on the author's competence, the expected volume of the text and the course of the event itself (the more dynamic and abundant with important moments it is, the less space there is to describe them in detail).
} 
The following components of the structural pattern may be distinguished in sports reports on the basis of the analysis of press publications:

- the headline, which contains the most important information, yet is often worded in a way that intrigues the reader (occasionally replaced with an ordinary notification about the score), e.g. Klitschko bored us again ${ }^{20}$.

- the lead, which supplements the title, summarizes the reported event or draws attention to one of its fragments, e.g.: "The world champion deservedly prevailed again, but the audience at Madison Square Garden in New York was not moved"21.

- the body, that is the proper report from the course of an event ${ }^{22}$.

The headlines of sports reports do not always directly inform about the subject of the text. Apart from concrete titles, relatively clear and understandable (informational texts, such as news, are characterized by these features ${ }^{23}$ ), e.g. The unrelenting defence secured the win ${ }^{24}$, Real killed by Suarez's goa ${ }^{25}$, League classic ends with a draw ${ }^{26}$, the mysterious and original coexist, e.g. Wista's lavender colours $^{27}$, Without anaesthesia ${ }^{28}$, Blessed left-handedness ${ }^{29}$, California shocked by Polish thunders ${ }^{30}$, Europe gets closer ${ }^{31}$, Evening under the whip ${ }^{32}$. The main purpose of such titles is not to convey condensed information about the event (although they do that to some extent), but to intrigue the reader or attractively summarize the competition. This feature corresponds to aesthetic or feuilletonistic utterances (including the review).

The mysteriousness of a headline leads to the fact that it does not fulfil some of the aims which are traditionally attributed to it; it may, among other things, make the interpretation of the whole utterance difficult or mislead the recipient as to its subject matter or context ${ }^{33}$. As Ewa Wolańska stresses, the dominance of the informative or

${ }^{20}$ A. Wasik, „Kliczko znów zanudził”, Sport 2015, No 97, p. 20.

${ }^{21}$ Ibid.

${ }^{22}$ Cf. the outline of press news structure presented by Maria Wojtak: "The canonical model of news $[\ldots]$ is structured as follows:

- the heading, which briefly informs about an event or a fact;

- the lead, which is concise or summarizing;

- the body in the shape of a report or coverage [...]" (M. Wojtak, op. cit., p. 79).

${ }^{23}$ Cf. W. Pisarek, „Nagłówki wiadomości w dziennikach”, Zeszyty Prasoznawcze 1965, No. 1, p. 34.

${ }^{24}$ W. Osiński, „Obrona z żelaza dała zwycięstwo”, Przeglad Sportowy 2015, No. 21, pp. 2-3.

${ }^{25}$ D. Wołowski, „Real zabity golem Suareza”, Gazeta Wyborcza 2015, No. 69, p. 23.

${ }^{26}$ K. Ferszter, „Ligowy klasyk na remis”, Gazeta Stoteczna 2015, No. 62, p. 12.

${ }^{27}$ G. Wojowicz, „Lawendowe barwy Wisły”, Przeglad Sportowy 2015, No. 17, p. 10.

${ }^{28}$ D. Bizewski, „Bez znieczulenia”, Sport 2015, No. 62, p. 11.

${ }^{29}$ M. Żukowski, „Błogosławiona leworęczność”, Rzeczpospolita 2015, No. 127, p. A16.

${ }^{30}$ P. Osiak, „Polskie grzmoty zatrzęsły Kalifornią”, Przegląd Sportowy 2015, No. 91, pp. 18-19.

${ }^{31}$ S. Szczepłek, „Coraz lepiej widać Europę”, Rzeczpospolita 2015, No. 137, p. A16.

${ }^{32}$ R. Werner, „Wieczór pod batem”, Sport 2015, No. 48, p. 3.

${ }^{33}$ About the functions of titles see i.a. W. Pisarek, „Poznać prasę po nagłówkach!”, Ośrodek Badań Prasoznawczych RSW „Prasa”, Cracow 1967; K. Piotrowska, „Tytuł artykułu i jego wpływ na rozumienie tekstu", Zeszyty Prasoznawcze 1983, No. 4, pp. 45-51. 
acquiring function depends on the genre to which the utterance belongs ${ }^{34}$. The perspective which takes family resemblance into account and treats the genres as types makes it possible to perceive texts in terms of their distance from the model. A text with an intriguing headline is farther from the centre of the generic field.

In such conditions, the burden of informing the readers about an event is taken over by the lead. In informational texts it supplements the title and builds up the information with the most important details. There are two types of leads in the sports report:

- directly informing about the result of the competition (their form and function is closer to signals $\left.{ }^{35}\right)$, e.g.:

Alejandro Valverde won the classic Liege-Bastonge-Liege. Michał Kwiatkowski arrived in $21^{\text {st }}$ place ${ }^{36}$.

The Poles lost 26-29 during the Inauguration of the World Cup in Qatar ${ }^{37}$.

- summarizing the course of the competition, e.g.:

PGE GKS - Zawisza 1:4. After 11 minutes of the match, the newcomers were on their knees and rose only for a moment ${ }^{38}$.

It was an exceptionally grim spectacle. Without an audience, without a good script to predict the surprising turn of events and with a quietly lowered curtain. This is how the Polish champions said goodbye to Europe ${ }^{39}$.

Apart from these two basic functions, some leads also explain the mysterious title, as in the examples below:

\section{Wista's lavander colours}

Jantel Lavender's spectacular performance and an impressive victory by Wisła CanPack Kraków in group A of Euroleague. In group B Energa learned a lesson from Fenerbahce $^{40}$.

The decade interrupted!

The team from Tychy made their fans' dream come true after 10 years ${ }^{41}$.

${ }^{34}$ E. Wolańska, „Kompozycja i spójność wypowiedzi językowej. Strategiczne pozycje tekstowe”, in: „Praktyczna stylistyka nie tylko dla polonistów”, ed. E. Bańkowska, A. Mikołajczuk, Książka i Wiedza, Warsaw 2003, p. 126.

${ }^{35}$ Cf. M. Wojtak's considerations concerning the lead in the press news (op. cit., p. 79).

${ }^{36}$ O. Kwiatkowski, „Hiszpan - król Ardenów”, Rzeczpospolita 2015, No. 97, p. A14.

${ }^{37}$ P. Rozpara, „Prezent dla Niemców”, Gazeta Wyborcza 2015, No. 13, p. 42.

${ }^{38}$ T. Pomarkiewicz, „Wybili GKS ekstraklasę z głowy”, Przeglad Sportowy 2015, No. 126, p. 9.

${ }^{39}$ R. Werner, „Wieczór”, op. cit.

${ }^{40}$ G. Wojowicz, „Lawendowe barwy”, op. cit.

${ }^{41}$ W. Sowiński, „Dekada przerwana!”, Sport 2015, No. 78, p. 27. 
In the first example of the lead, the reader learns why Wisła Can-Pack Kraków have lavender colours. It is a metaphor alluding to the name of the best player of the game, Jantel Lavender. In the second case, the mysterious title The decade interrupted! refers to the GKS Tychy team breaking a ten-year long series of losing league seasons. Admittedly, neither the headline nor the lead indicate which sport is concerned but one may find that out from the title of the column (Hockey) or from the photography presenting the team of the new Polish Champions in ice hockey.

Leads in sports reports are characterized by a definite departure from the reportorial paradigm. They mostly provide commentary, include statements made by the competitors (which serve as commentaries, in fact). They also take the form of mixed or dramatized leads ${ }^{42}$, which corresponds to the essayistic intention:

The team from Rzeszów clearly proved to the players of Lotos Trefl Gdańsk that they are the favourites for the final ${ }^{43}$.

Andrzej Fonfara has achieved one of the biggest triumphs in the history of Polish professional boxing ${ }^{44}$.

Robert Lewandowski has gone down in history, but it is still not the dream team we have been waiting for ${ }^{45}$.

Having summarized the considerations concerning the initial fragments of texts, one may assume that because of the way in which titles and leads are usually formed in the practice of journalism, the sports report becomes closer to texts whose primary intention is feuilletonistic or essayistic; their headlines serve as "enticing advertisements" evaluations and interpretations of events.

If we accept the definitions of the genre quoted at the beginning, the body of a sports report ought to include a chronological and impartial record of the sequence of certain events. The entirety of the utterance should revolve around the course of the sports event which is discussed in the text. In principle, sports reporters indeed refer to the course of the competition, although out of necessity (limited space in the magazine) their descriptions are not very detailed, involve general impressions (e.g. "the match got its colour back, and both teams had a few more opportunities to change the result"47) and concern only selected fragments of the event (e.g. goals, injuries, the decisive moments in a race etc.).

\footnotetext{
${ }^{42}$ Cf. M. Wojtak, „Gatunki”, op. cit., p. 83.

43 J. Bochenek, „Nokaut na początek”, Sport 2015, No. 88, p. 14.

${ }^{44}$ P. Osiak, „Polskie grzmoty”, op. cit.

${ }^{45}$ S. Szczepłek, „Coraz lepiej”, op. cit.

${ }^{46}$ W. Pisarek, „Nagłówki wiadomości”, op. cit., p. 34.

${ }^{47}$ Z. Cieńciała, „Stadiony świata!”, Sport 2015, No. 55, p. 3.
} 
It is quite frequent, however, that a report includes only a few references to the action understood as a chain of subsequent facts. Then, marginal information becomes the main subject of the journalist's utterance, for example, roster-related problems of a team, the deepening crisis of players' form or the effect that the score has on the league table. The reporter briefly discusses the competition and instead focuses on searching for the reasons behind the final result (which is characteristic of the essayistic paradigm). In that case, the report becomes dominated by commentaries.

The main part of the sports reporter's utterance may, therefore, contain both the record of consecutive facts and additional elements, e.g. quotes from the comments made by players, referees (rarely - referees are not allowed to comment on their own decisions); it also includes contextual information regarding, among other things, the records, anniversaries, injuries, situation in the league table, behaviour of supporters, etc.

The language of sports reports also goes beyond typically informative neutrality ${ }^{48}$. This is especially visible in the distinct presence of the author. Admittedly, the reporters do not use first person forms (third person narration is dominant), yet they reveal themselves through the use of evaluative or judgemental vocabulary, e.g.:

On April Fools' Day, the team from Jastrzębia Góra, led by coach Robert Kalaber, could not possibly defeat the winners of the Polish Cup on their own rink because their defence was disastrous. Tomaš Protivny's performance was particularly shameful as he acted like a fifth column in JKH's team ${ }^{49}$.

This victory would not have been possible without the excellent as ever Michał Kubiak, whose series of serves gave the advantage to his team in the second, decisive set, without the blocks and attacks of the sensational rookie Mateusz Bieniek and Mateusz Mika's good performance, who had worse moments during the tour abroad $^{50}$.

The frequent use of colloquial vocabulary, often of a metaphorical nature, also draws attention:

Yesterday's meeting, which opened the third series of the rematch round, was a clash of two "hot" teams - Zagłębie had won their six previous games, and Legia had achieved decent victories over a strong Miasto Szkła Krosno and Znicz Basket Pruszków ${ }^{51}$ at their home stadium.

\footnotetext{
${ }^{48}$ Obviously, neutrality is concerned here only approximately.

${ }^{49}$ W. Sowiński, „Minuta walki to za mało”, Przeglad Sportowy 2015, No. 77, p. 19.

${ }^{50}$ K. Drąg, „Twierdza Teheran zdobyta”, Przeglad Sportowy 2015, No. 149, p. 14.

${ }^{51}$ Ł. Cegliński, „Legia przegrała z Zagłębiem”, Gazeta Stołeczna 2015, p. 16.
} 
Inaki Astiz angrily kicked the ball in the direction of the stand and the remaining Varsovians froze in disbelief. [...] What only a few believed possible happened Legia cracked ${ }^{52}$.

While the high frequency of colloquialisms in sports reports may be explained by the fact that the majority of them belong to the jargon which is familiar to sportsmen, journalists and spectators, it does move the genre away from the requirement of maintaining stylistic neutrality of language. The phraseology used by sports reporters has a similar, jargon-like and colloquial character:

And as early as 82 seconds after the match began, the second attack was so well executed that Rzeszutko's goal into the empty net was just a formality ${ }^{53}$.

Our team built a wall in which the tough Scandinavians could not find a breach for a long time ${ }^{54}$.

Idiomatic expressions which appear in the researched material convey emotional charges. They allow senders to assume the role of commentators of the events, but also of experts (the knowledge of the sport's unofficial language, the ability to assess a particular play or the abilities of a sportsman). In such case, the authors of these texts no longer act as observers who give an account of the events, which the informational convention requires from them.

The roles assumed by senders distance the sports report from the model of the genre. Questions arise as to the basic functions of the text. If the sports report was to be approached as any other kind of report, then its most important task would be to inform the recipients about the course of a given event (a match, fight, race etc.). The analysis of reports published in the press shows that, in practice, the actual reporting is sidetracked. The elements specific to a commentary, in which the authors interpret, evaluate, summarize and express their own opinions, are emphasized. Interpretations and evaluations are interwoven with facts (not always directly concerning the course of the competition) and constitute an integral part of the utterance.

Which functions should be assigned to the sports report? According to Phil Andrews, it is predominantly supposed to deliver a second-hand experience to those who did not see the competition. It also enables the recipients who were in the stands or followed the TV/radio transmission to relive their emotions. Furthermore, the report allows the reader to compare his own observations with the journalist's assessments, and provides an analysis of the event or information outlining the context. The last function of these types of texts is to entertain ${ }^{55}$.

\footnotetext{
${ }^{52}$ P. Zych, „Lech po liftingu Skorży”, Gazeta Wyborcza 2015, No. 68, p. 27.

53 J. Dusik, „Awans i strata”, Sport 2015, No. 54, p. 26.

${ }^{54}$ W. Osiński, „Obrona”, op. cit.

${ }^{55}$ Cf. P. Andrews, „Dziennikarstwo sportowe”, transl. M. Lorek, Wydawnictwo UJ, Cracow 2009, p. 51.
} 
Admittedly, Andrews does not establish any hierarchy of importance, yet one might assume that putting the "second-hand experience" first shows that it is more important than the other functions. Research conducted on the press material ${ }^{56}$ revealed that the authors do not restrict themselves to recording the chronological sequence of events. The summary and evaluation provided in condensed form are in the foreground. Hence the tendency of the reporters to choose only some of the aspects of the event and base their comprehensive interpretation and opinion on them.

The conclusions drawn so far from the analysis indicate that sports reports realize the essayistic intention to an increasing degree. Their particular examples display mixed sets of properties and may be placed at the borderline between two paradigms. Perhaps, following Wojtak's proposals ${ }^{57}$, they may be considered as an adaptational variety of the generic model, which uses the elements of other types of utterances - reviews.

According to Stownik terminologii medialnej (Eng. Dictionary of media terms), "the review discusses and/or evaluates an artistic or scientific work, or other copyrighted publication made in the press or other mass media" 58 . Just like the reviewer, the reporter discusses the subject of his/her text (sports competition in this case). There is no need for it to be detailed, which would explain the tendency to choose only the most important fragments of the event. What is more, both the report and the review constitute an expression of the sender's standpoint. Apart from informative fragments, they include general evaluations, interpretations and critical analyses. The difference consists in the fact that informative elements have an auxiliary role in the review, while in the report, judging from its definition, they should dominate.

The connection between the sports report and the review is to some extent historical as well. The beginnings of Polish sports journalism, which date back to the turn of the nineteenth and twentieth century, were characterized by, among other things, the lack of terminological organisation. The present-day report was initially established as a review (or discussion; this term has already appeared in the quoted definition of a review), and reporters were often referred to as reviewers ${ }^{59}$. Even then, the journalists had a distinct propensity to evaluate the competitions which

\footnotetext{
${ }^{56}$ It should be remembered that reports are also published on the internet. In this case, the texts and descriptions of competitions are more extensive and detailed because there are no limitations on the volume of the text. However, they still include evaluations and elements characteristic of a commentary.

${ }^{57}$ M. Wojtak, „Gatunki”, op. cit.

${ }^{58}$ A. Kaliszuk, K. Wolny-Zmorzyński, „Recenzja”, in: „Słownik terminologii”, op. cit., p. 181.

${ }^{59}$ Cf.: "The evaluation of Polish players' performance in Hungarian press certainly pleased our reviewers; our sports community had a chance to learn that even far more professional reporters not only do not differ in their tasks, but also their assessment is incorrect in many respects („Po zawodach Węgry - Polska”, Przeglad Sportowy 1922, No. 1, p. 8.). This example proves that the terms "reporter" and "reviewer" were treated interchangeably.
} 
they presented to readers. In many cases, providing a commentary on the events becomes the dominant function of such an utterance. At the level of realization, the essayistic nature of the sports report may be perceived as its illocutionary dominant.

\section{Bibliography}

Andrews P., „Dziennikarstwo sportowe”, transl. M. Lorek, Wydawnictwo Uniwersytetu Jagiellońskiego, Cracow 2009.

Balcerzan E., „W stronę genologii multimedialnej”, Teksty Drugie 1999, No. 6, pp. 7-24.

Bauer Z., „Gatunki dziennikarskie”, in: „Dziennikarstwo i świat mediów”, ed. Z. Bauer, E. Chudziński, Universitas, Cracow 2010, pp. 255-280.

Bizewski D., „Bez znieczulenia”, Sport 2015, No. 62, p. 11.

Bochenek J., „Nokaut na początek”, Sport 2015, No. 88, p. 14.

Cegliński Ł., „Legia przegrała z Zagłębiem”, Gazeta Stołeczna 2015, p. 16.

Chyliński M., Russ-Mohl S., „Dziennikarstwo”, Grupa Wydawnicza Polskapresse, Warsaw 2008.

Cieńciała Z., „Stadiony świata!”, Sport 2015, No. 55, p. 3.

Drąg K., „Twierdza Teheran zdobyta”, Przeglad Sportowy 2015, No. 149, p. 14.

Dusik J., „Awans i strata”, Sport 2015, No. 54, p. 26.

Ferszter K., „Ligowy klasyk na remis”, Gazeta Stołeczna 2015, No. 62, p. 12.

Fras J., „Dziennikarski warsztat językowy”, $2^{\text {nd }}$ ed., en., rev. ed., Wydawnictwo Uniwersytetu Wrocławskiego, Wroclaw 2005, p. 86.

Fras J., „O typologii wypowiedzi medialnych i dziennikarskich”, Wydawnictwo Uniwersytetu Wrocławskiego, Wroclaw 2013.

Gajda S., „Gatunkowe wzorce wypowiedzi”, in: „Współczesny język polski”, ed. J. Bartmiński, Wydawnictwo Uniwersytetu Marii Curie-Skłodowskiej, Lublin 2012, pp. 255-268.

Grochala B., „Komentarz (sportowy), relacja (sportowa), sprawozdanie (sportowe) - przegląd stanowisk", Acta Universitatis Lodziensis. Folia Litteraria Polonica 2012, No. 3, pp. 95-105.

Kozieł A., „Gatunki dziennikarskie - rodowód, cechy i funkcje”, in: „O warsztacie dziennikarskim”, ed. J. Adamowski, Oficyna Wydawnicza Aspra JR, Warsaw 2002, p. 109-127.

Kwiatkowski O., „Hiszpan - król Ardenów”, Rzeczpospolita 2015, No. 97, p. A14.

Maziarski J., „Informacja”, in: “Encyklopedia wiedzy o prasie”, ed. J. Maślanka, Zakład Narodowy im. Ossolińskich, Wroclaw 1976, pp. 107-109.

Maziarski J., „Metodologiczne problemy nauki o gatunkach dziennikarskich”, in: „Metody i techniki badawcze w prasoznawstwie", Vol. 1, ed. M. Kafel, Wydawnictwa Uniwersytetu Warszawskiego, Warsaw 1969, pp. 113-129.

Maziarski J., „Sprawozdanie”, in: „Encyklopedia wiedzy o prasie”, ed. J. Maślanka, Zakład Narodowy im. Ossolińskich, Wroclaw 1976, p. 224.

Osiak P., „Polskie grzmoty zatrzęsły Kalifornią”, Przegląd Sportowy 2015, No. 91, pp. $18-19$.

Osiński W., „Obrona z żelaza dała zwycięstwo”, Przegląd Sportowy 2015, No. 21, pp. 2-3.

Piotrowska K., „Tytuł artykułu i jego wpływ na rozumienie tekstu”, Zeszyty Prasoznawcze 1983, No. 4, pp. 45-51.

Pisarek W., „Nagłówki wiadomości w dziennikach”, Zeszyty Prasoznawcze 1965, No. 1, p. 34.

Pisarek W., „Poznać prasę po nagłówkach!”, Ośrodek Badań Prasoznawczych RSW „Prasa”, Cracow 1967. 
Pomarkiewicz T., „Wybili GKS ekstraklasę z głowy”, Przeglad Sportowy 2015, No. 126, p. 9.

Rozpara P., „Prezent dla Niemców”, Gazeta Wyborcza 2015, No. 13, p. 42.

Sowiński W., „Dekada przerwana!”, Sport 2015, No. 78, p. 27.

Sowiński W., „Minuta walki to za mało”, Przeglad Sportowy 2015, No. 77, p. 19.

Szczepłek S., „Coraz lepiej widać Europę”, Rzeczpospolita 2015, No. 137, p. A16.

Wasik A., „Kliczko znów zanudził”, Sport 2015, No 97, p. 20.

Wegner J., „Metoda systematyzowania form dziennikarskich”, in: „Metody i techniki badawcze w prasoznawstwie", Vol. 1, ed. M. Kafel, Wydawnictwo Uniwersytetu Warszawskiego, Warsaw 1969, pp. 130-144.

Werner R., „Wieczór pod batem”, Sport 2015, No. 48, p. 3.

Wojowicz G., „Lawendowe barwy Wisły”, Przeglad Sportowy 2015, No. 17, p. 10.

Wojtak M., „Gatunki prasowe”, Wydawnictwo Uniwersytetu Mari Curie-Skłodowskiej, Lublin 2004.

Wolańska E., „Kompozycja i spójność wypowiedzi językowej. Strategiczne pozycje tekstowe”, in: „Praktyczna stylistyka nie tylko dla polonistów”, ed. E. Bańkowska, A. Mikołajczuk, Książka i Wiedza, Warsaw 2003, p. 119-147.

Wolny-Zmorzyński K., „Sprawozdanie”, in: „Słownik terminologii medialnej”, ed. W. Pisarek, Universitas, Cracow 2006, p. 20.

Wolny-Zmorzyński K., Kaliszewski A., „Gatunki informacyjne”, in: K. Wolny-Zmorzyński, A. Kaliszewski, W. Furman, „Gatunki dziennikarskie. Teoria, praktyka, język”, Wydawnictwa Akademickie i Profesjonalne, Warsaw 2009, pp. 37-86.

Wołowski D., „Real zabity golem Suareza”, Gazeta Wyborcza 2015, No. 69, p. 23.

Wtorkiewicz A., „Stylistyka prasoznawcza - szkic problematyki i metod”, in: „Metody i techniki badawcze w prasoznawstwie", Vol. 3, ed. M. Kafel, Wydawnictwa Uniwersytetu Warszawskiego, Warsaw 1971, pp. 114-121.

Zych P., „Lech po liftingu Skorży”, Gazeta Wyborcza 2015, No. 68, p. 27.

Żukowski M., „Błogosławiona leworęczność”, Rzeczpospolita 2015, No. 127, p. A16.

\section{Rafał Siekiera}

\section{Reportorial or Essayistic Paradigm? - a Few Remarks about the Sports Report}

\section{(Summary)}

The article attempts to decide whether the sports report is more about the information or the commentary. On the basis of an analysis of press material, the author examines different characteristics of the genre and tries to determine their compatibility with the news canon. As the analysis shows, the contemporary sports report is less about news and more about commentary, interpretation and evaluation. Journalists tend to summarize the competition and briefly describe the course of events. It makes the sports report similar to press comment and review.

Keywords: press, sports report, stylistics. 